\title{
Helicobacter equorum sp. nov., a urease-negative Helicobacter species isolated from horse faeces
}

Correspondence
H. Moyaert
Hilde.Moyaert@UGent.be

\author{
H. Moyaert, ${ }^{1}$ A. Decostere, ${ }^{1}$ P. Vandamme, ${ }^{2}$ L. Debruyne, ${ }^{2}$ J. Mast, ${ }^{3}$ \\ M. Baele, ${ }^{1}$ L. Ceelen, ${ }^{1}$ R. Ducatelle ${ }^{1}$ and F. Haesebrouck ${ }^{1}$ \\ ${ }^{1}$ Department of Pathology, Bacteriology and Avian Diseases, Faculty of Veterinary Medicine, \\ Ghent University, Salisburylaan 133, B-9820 Merelbeke, Belgium \\ ${ }^{2}$ Department of Biochemistry, Physiology and Microbiology, Faculty of Sciences, Ghent \\ University, Ledeganckstraat 35, B-9000 Ghent, Belgium \\ ${ }^{3}$ CODA - CERVA - VAR, Groeselenberg 99, B-1180 Brussels, Belgium
}

Gram-negative, curved, motile bacteria (strains $\mathrm{EqF}^{\top}{ }^{\top}$ and $\mathrm{EqF} 2$ ) were isolated from faecal samples from two clinically healthy horses. Both strains possessed a single, monopolar, sheathed flagellum and were urease-negative. The novel strains grew at $37^{\circ} \mathrm{C}$ under microaerobic conditions and were positive for oxidase, catalase and alkaline phosphatase activities. The isolates reduced nitrate to nitrite, but $\gamma$-glutamyl transpeptidase activity was not detected. The novel isolates did not grow at $42{ }^{\circ} \mathrm{C}$ or on media containing $1 \%$ glycine. They were resistant to cephalotin and nalidixic acid and susceptible to metronidazole. Analysis of the 16S and 23S rRNA gene sequences of the two novel strains identified them as representing a single species within the genus Helicobacter. In terms of 16S rRNA gene sequence similarity, Helicobacter pullorum and Helicobacter canadensis were the most closely related species (98\% similarity). 23S rRNA gene sequence analysis also classified strains $\mathrm{EqF}^{\top}$ and $\mathrm{EqF} 2$ within the enterohepatic division of the genus Helicobacter, but only $94 \%$ similarity was detected with $H$. pullorum and $H$. canadensis, which are helicobacters with unsheathed flagella. The most closely related species in terms of $23 S$ rRNA gene sequence similarity was Helicobacter canis (95\%). Numerical analysis of whole-cell protein extracts by SDS-PAGE was performed and the novel isolates were clearly differentiated from $H$. pullorum, $H$. canadensis, $H$. canis and other species of the genus Helicobacter. This finding was also confirmed by sequence analysis of the $h s p 60$ gene. On the basis of these genetic, biochemical and protein data, the isolates are classified as representing a novel species, for which the name

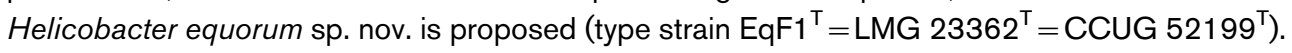

The genera Helicobacter, Campylobacter, Arcobacter and Wolinella belong phylogenetically to the Epsilonproteobacteria, formerly known as the $\varepsilon$-subclass of the Proteobacteria (Murray et al., 1990). Over the last decade, species of the genus Helicobacter have been described in a wide variety of animal hosts, including wild birds, chickens, dogs, cats, cattle, sheep, swine, rodents, non-human primates, cheetahs, ferrets, rabbits, dolphins and whales (Whary \& Fox, 2004; Van den Bulck et al., 2005). Dimola \&

The GenBank/EMBL/DDBJ accession numbers for the 16S rRNA, 23S rRNA and $h s p 60$ gene sequences of strain $\mathrm{EqF}^{\top}{ }^{\top}$ are D0307735, D0307737 and DQ888713, respectively. The accession numbers for the 16S rRNA, 23S rRNA and hsp60 gene sequences of strain EqF2 are DQ307736, DQ307738 and DQ888714, respectively.

Figures showing transmission electron microscope images of cells of strains $\mathrm{EqF}^{\top}$ and $\mathrm{EqF} 2$ and phylogenetic trees based on $16 \mathrm{~S}$ rRNA, 23S rRNA and $h s p 60$ gene sequences are available as supplementary material in IJSEM Online. Distance matrix analyses for the three genes are available as supplementary tables.
Caruso (1999) reported the presence of rod-shaped organisms with a morphology similar to that commonly reported for Helicobacter pylori in the stomach of 15 horses. However, after this single preliminary report, horses have never been confirmed as hosts for Helicobacter-like organisms. Here we report the isolation of a novel Helicobacter species from horse faeces.

Two bacterial strains, designated $\mathrm{EqF}^{\mathrm{T}}$ and $\mathrm{EqF} 2$, were isolated from faecal samples from a 3 - and a 4-year-old horse, respectively. Both horses were clinically healthy and were stalled at the Faculty of Veterinary Medicine, Ghent University, Belgium. Samples were inoculated on brain heart infusion (BHI) agar (Oxoid), supplemented with $10 \%$ horse blood, $15 \mu \mathrm{g} \mathrm{ml}^{-1}$ amphotericin B (Fungizone, Bristol-Myers Squibb) and Vitox (Oxoid) by using the filter technique of Steele \& McDermott (1984). Plates were incubated, lids uppermost, at $37^{\circ} \mathrm{C}$ under microaerobic conditions $\left(5 \% \mathrm{H}_{2}, 5 \% \mathrm{CO}_{2}, 5 \% \mathrm{O}_{2}\right.$ and $\left.85 \% \mathrm{~N}_{2}\right)$ and examined daily. After 3-4 days incubation, growth 
appeared as a thin, transparent, spreading film and microscopic examination revealed the presence of spiral, motile bacteria. In cultures of more than 5 days, coccoid forms predominated.

Growth of both strains was examined at 25,37 and $42{ }^{\circ} \mathrm{C}$ under microaerobic conditions and at $37^{\circ} \mathrm{C}$ under aerobic, microaerobic and anaerobic conditions. Tolerance of $1 \%$ bile, $1 \%$ glycine and $1.5 \% \mathrm{NaCl}$ was determined as previously described (On \& Holmes, 1991). The isolates were Gram-stained and examined for catalase activity by standard microbiological methods (Wolf et al., 1975). Oxidase activity was determined with Bactident oxidase strips (Merck). The following biochemical analyses were performed with the API-Campy identification system (bioMérieux): urease activity, reduction of nitrates, esterase activity, hydrolysis of hippurate, $\gamma$-glutamyl transferase activity, reduction of triphenyl tetrazolium chloride, alkaline phosphatase activity, production of $\mathrm{H}_{2} \mathrm{~S}$, assimilation of glucose and pyrrolidonyl-, L-arginine- and L-aspartate arylamidase activities. Indoxyl acetate hydrolysis was determined as previously described by Mills \& Gherna (1987). Susceptibility to cephalotin (30 $\mu \mathrm{g}$ per disc) and nalidixic acid (30 $\mu \mathrm{g}$ per disc) (Becton Dickinson) was examined by culturing the organisms in the presence of discs impregnated with the antimicrobial agent as described by Melito et al. (2001). Melito's technique was slightly modified in that plates were incubated for $72 \mathrm{~h}$ before examination instead of $48 \mathrm{~h}$. Growth in the presence of metronidazole was determined with BHI agar (Oxoid) containing $10 \%$ horse blood and $5 \mu \mathrm{g} \mathrm{ml}^{-1}$ of the test compound. DNase activity was examined as described by Devriese \& Oeding (1975). All tests were performed in two time-independent assays with freshly prepared media.

A detailed list of results is given in the species description below and a comparison of the most important phenotypic characteristics of the novel strains with those of other Helicobacter species is shown in Table 1.

The morphology of strains $\mathrm{EqF1}^{\mathrm{T}}$ and $\mathrm{EqF} 2$ was studied by means of transmission electron microscopy after negative staining with $2 \%$ uranyl acetate as described by Houf et al. (2005) and after ultrathin sectioning as described by Mast et al. (2005).

Cells appeared as slightly curved rods, $1.5-4 \mu \mathrm{m}$ in length and $0.3 \mu \mathrm{m}$ in width. As seen for Helicobacter pullorum and most of the Helicobacter cinaedi strains, cells of the novel strains carried a single flagellum. In contrast with $H$. pullorum, strains $\mathrm{EqF}^{\mathrm{T}}$ and EqF2 possess sheathed flagella. No periplasmic fibril was detected. Coccoid forms were also observed. Electron micrographs of cells of strain $\mathrm{EqF}^{\mathrm{T}}$ are available as Supplementary Fig. S1a-d in IJSEM Online.

DNA was extracted from a loopful of cells using the alkaline lysis method of Baele et al. (2000). To determine if the strains were members of the genus Helicobacter, bacterial DNA was amplified by PCR using the Helicobacter genus-specific primers described by Germani et al. (1997) and analysed by gel electrophoresis. For both isolates, a $399 \mathrm{bp}$ fragment was obtained, indicating that they are members of the genus Helicobacter.

PCR amplification of the 16S rRNA gene was performed using primers $\alpha \beta$-NOT and $\omega_{\mathrm{MB}}$ and amplicons were sequenced using primers $\mathrm{pD}, \mathrm{Gamma}^{\star}, 3$ and $\mathrm{O}^{\star}$ (Coenye et al., 1999) as described previously (Baele et al., 2001). The sequences were compared with entries in the NCBI GenBank using the BLAST search tool. Fragments of 1454 and 1343 bp were obtained that showed $98 \%$ gene sequence similarity to H. pullorum and Helicobacter canadensis. Phylogenetic analysis was performed with KODON software (Applied Maths). A comparison of the $16 \mathrm{~S}$ rRNA gene sequences of strains $\mathrm{EqF}^{\mathrm{T}}$ and $\mathrm{EqF} 2$ with those of other Helicobacter species is shown in a distance matrix (see Supplementary Table S1 in IJSEM Online). A phylogenetic tree obtained from this matrix using the neighbour-joining method is also available in IJSEM Online as Supplementary Fig. S2.

In the past, several studies have revealed that the comparison of 16S rRNA gene sequences alone is not sensitive enough to identify strains to the species level (Stackebrandt \& Goebel, 1994; Jalava et al., 1997; Vandamme et al., 2000). Dewhirst et al. (2005) recently suggested that $16 \mathrm{~S}$ rRNA gene sequence data do not always faithfully reflect phylogenetic relationships and that $23 \mathrm{~S}$ rRNA gene sequence data are significantly more reliable for the identification and classification of helicobacters due to the threefold-higher number of informative bases. For strains $\mathrm{EqF}^{\mathrm{T}}$ and $\mathrm{EqF} 2, H$. pullorum and $H$. canadensis were the most closely related species in terms of $16 \mathrm{~S}$ rRNA gene sequence similarity (98\%). However, strains $\mathrm{EqF1}^{\mathrm{T}}$ and $\mathrm{EqF} 2$ possess a single, monopolar, sheathed flagellum, while $H$. pullorum and $H$. canadensis are unsheathed flagellum-bearing helicobacters (Dewhirst et al., 2005). Therefore, we also amplified the $23 \mathrm{~S}$ rRNA genes of strains $\mathrm{EqF}^{\mathrm{T}}$ and $\mathrm{EqF} 2$ using PCR primers O68 and M89; amplicons were sequenced by using the full set of 20 primers as described by Dewhirst et al. (2005). The sequences obtained were compared with sequences in the NCBI GenBank database using the BLAST search tool. Fragments of 2728 and $2712 \mathrm{bp}$ were obtained which showed only $94 \%$ gene sequence similarity to $H$. pullorum and $H$. canadensis. The most closely related species in terms of 23S rRNA gene sequence similarity was Helicobacter canis $(95 \%)$. A distance matrix calculated using KODON software (Applied Maths) is shown in Supplementary Table S2 in IJSEM Online. A phylogenetic tree obtained from this matrix using the neighbour-joining method is also available as Supplementary Fig. S3).

Since the 16S and 23S rRNA gene sequence phylogenies for strains $\mathrm{EqF1}^{\mathrm{T}}$ and $\mathrm{EqF2}$ were contradictory, a third phylogenetically informative gene, the $h s p 60$ gene, was sequenced as described previously (Mikkonen et al., 2004). The hsp60 sequences were compared with those in the NCBI GenBank database using the BLAST search tool. Fragments of 518 bp were obtained which showed only $74 \%$ and $78 \%$ 
Table 1. Phenotypic characteristics that differentiate Helicobacter equorum sp. nov. from other Helicobacter species

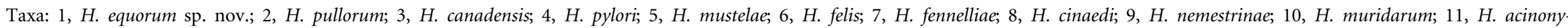

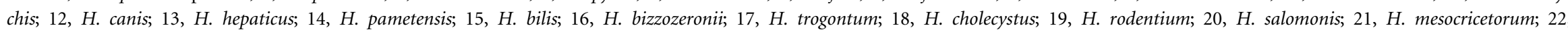

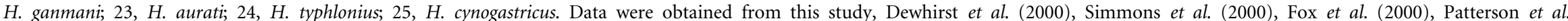

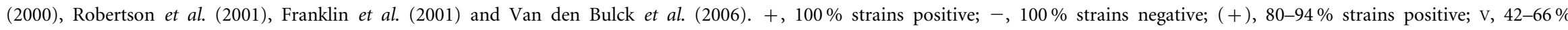
strains positive; (-), 7-33\% strains positive; $\mathrm{s}$, sensitive; R, resistant; I, intermediate; ND, not determined.

\begin{tabular}{|c|c|c|c|c|c|c|c|c|c|c|c|c|c|c|c|c|c|c|c|c|c|c|c|c|c|}
\hline Characteristic & 1 & 2 & 3 & 4 & 5 & 6 & 7 & 8 & 9 & 10 & 11 & 12 & 13 & 14 & 15 & 16 & 17 & 18 & 19 & 20 & 21 & 22 & 23 & 24 & 25 \\
\hline Catalase production & + & + & + & + & + & + & $(+)$ & $(+)$ & + & + & + & - & + & $(+)$ & + & + & + & + & + & + & + & $(-)$ & + & + & + \\
\hline Nitrate reduction & + & + & $\mathrm{V}$ & - & + & + & - & + & - & - & - & - & + & + & + & + & + & + & + & + & $(+)$ & + & - & $\mathrm{V}$ & + \\
\hline Urease & - & - & - & + & + & $(+)$ & - & - & + & + & + & - & + & - & + & $(+)$ & + & - & - & + & - & - & + & - & + \\
\hline Alkaline phosphate hydrolysis & + & - & - & + & + & $\mathrm{V}$ & $(-)$ & $(-)$ & + & + & + & + & - & $(+)$ & - & $\mathrm{V}$ & - & + & - & $\mathrm{V}$ & + & - & - & - & + \\
\hline$\gamma$-Glutamyl transpeptidase & - & ND & - & + & + & + & - & - & $\mathrm{ND}$ & + & + & + & - & - & + & + & + & - & - & + & - & $\mathrm{ND}$ & + & - & + \\
\hline Indoxyl acetate hydrolysis & - & - & + & $(-)$ & + & $(-)$ & + & $(-)$ & - & - & $(-)$ & + & + & - & - & $(-)$ & - & - & - & $(-)$ & $\mathrm{ND}$ & - & + & - & - \\
\hline Growth at $42^{\circ} \mathrm{C}$ & - & + & + & $(-)$ & $\mathrm{V}$ & $\mathrm{V}$ & $(-)$ & $\mathrm{V}$ & + & - & $(-)$ & + & - & + & + & $\mathrm{V}$ & + & + & + & - & + & - & + & + & - \\
\hline Growth on $1 \%$ glycine & - & - & + & - & - & - & - & - & - & - & - & - & + & $\mathrm{v}$ & + & $(-)$ & ND & + & + & - & - & - & - & + & - \\
\hline \multicolumn{26}{|l|}{ Susceptibility to: } \\
\hline Nalidixic acid $(30 \mu \mathrm{g})$ & $\mathrm{R}$ & $\mathrm{R}$ & $\mathrm{R}$ & $\mathrm{R}$ & S & $\mathrm{R}$ & s & s & $\mathrm{R}$ & $\mathrm{R}$ & $\mathrm{R}$ & s & $\mathrm{R}$ & S & $\mathrm{R}$ & $\mathrm{R}$ & $\mathrm{R}$ & I & $\mathrm{R}$ & $\mathrm{R}$ & S & s & s & s & $\mathrm{ND}$ \\
\hline Cephalotin $(30 \mu \mathrm{g})$ & $\mathrm{R}$ & s & $\mathrm{R}$ & s & $\mathrm{R}$ & s & s & I & s & $\mathrm{R}$ & s & I & $\mathrm{R}$ & s & $\mathrm{R}$ & s & $\mathrm{R}$ & $\mathrm{R}$ & $\mathrm{R}$ & s & $\mathrm{R}$ & $\mathrm{R}$ & $\mathrm{R}$ & $\mathrm{R}$ & ND \\
\hline Periplasmic fibril & - & - & - & - & - & + & - & - & - & + & - & - & - & - & + & - & + & - & - & - & - & - & + & - & + \\
\hline No. flagella per cell & 1 & 1 & $1-2$ & $4-8$ & $4-8$ & $14-20$ & 2 & $1-2$ & $4-8$ & $10-14$ & $2-5$ & 2 & 2 & 2 & $3-14$ & $10-20$ & $5-7$ & 1 & 2 & $10-23$ & 2 & 2 & $7-10$ & 2 & $6-12$ \\
\hline Sheathed flagella & Yes & No & No & Yes & Yes & Yes & Yes & Yes & Yes & Yes & Yes & Yes & Yes & Yes & Yes & Yes & Yes & Yes & No & Yes & No & No & Yes & Yes & Yes \\
\hline Distribution of flagella* & $\mathrm{M}$ & $\mathrm{M}$ & $\mathrm{B}$ & $\mathrm{B}$ & $\mathrm{P}$ & B & $\mathrm{B}$ & $\mathrm{B}$ & B & B & $\mathrm{B}$ & $\mathrm{B}$ & $\mathrm{B}$ & $\mathrm{B}$ & $\mathrm{B}$ & $\mathrm{B}$ & B & $\mathrm{M}$ & $\mathrm{B}$ & $\mathrm{B}$ & B & B & $\mathrm{B}$ & $\mathrm{B}$ & B \\
\hline
\end{tabular}

${ }^{\star} \mathrm{B}$, Bipolar; $\mathrm{M}$, monopolar; $\mathrm{P}$, peritrichous. 


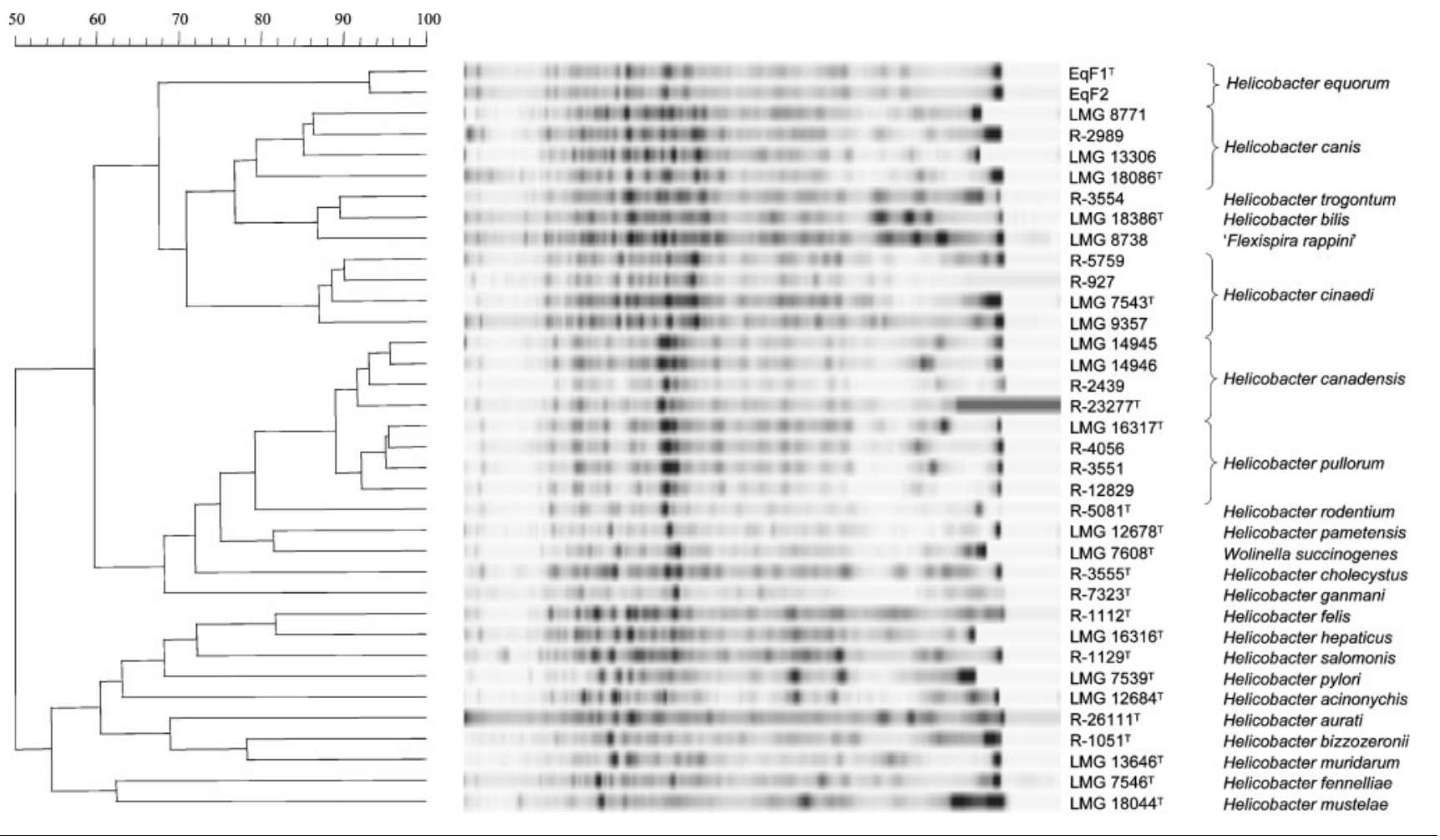

Fig. 1. Dendrogram derived from the numerical analysis of the whole-cell protein profiles of strains EqF1 ${ }^{\top}$ and $\mathrm{EqF} 2$ and other Helicobacter reference strains.

gene sequence similarity to $H$. pullorum and $H$. canis, respectively. The most closely related species in terms of hsp60 gene sequence similarity was Helicobacter hepaticus $(85 \%)$. A distance matrix, calculated using KODON software, is shown in Supplementary Table S3 in IJSEM Online. A phylogenetic tree obtained from this matrix using the neighbour-joining method is also available as Supplementary Fig. S4.

The taxonomic position of strains $\mathrm{EqF}^{\mathrm{T}}$ and $\mathrm{EqF} 2$ was further investigated by whole-cell protein profiling, a technique that is considered a good alternative for DNADNA hybridization experiments in the genus Helicobacter (Dewhirst et al., 2000; Vandamme et al., 2000). Whole-cell protein extracts of strains $\mathrm{EqF1}^{\mathrm{T}}$ and $\mathrm{EqF} 2$ were prepared and one-dimensional SDS-PAGE was performed as described previously (Pot et al., 1994). Whole-cell protein profiles of $H$. pullorum, $H$. canadensis, $H$. canis and other Helicobacter species were available from previous studies. Densitometric analysis, normalization and interpolation of the protein profiles and numerical analysis were performed using GelCompar version 4.2 software (Applied Maths). The similarity between all pairs of traces was expressed by using the Pearson product-moment correlation coefficient presented as percentages of similarity. A dendrogram derived from the numerical analysis of the protein profiles of both novel strains and of Helicobacter reference strains is shown in Fig. 1. The whole-cell protein profile of strains $\mathrm{EqF}^{\mathrm{T}}$ and EqF2 differed significantly from those of $H$. pullorum, $H$. canadensis, H. canis and other Helicobacter reference strains (the profiles of the H. equorum strains cluster at a correlation level of about $71 \%$ with those of several other Helicobacter species).

To determine the DNA G $+\mathrm{C}$ content of strain $\mathrm{EqF}^{\mathrm{T}}$, DNA was enzymically degraded into nucleosides as described by Mesbah et al. (1989). The nucleoside mixture obtained was then separated using a Waters Breeze HPLC system and XBridge Shield RP18 column thermostabilized at $37^{\circ} \mathrm{C}$. The solvent was $0.02 \mathrm{~mol} \mathrm{l}^{-1} \mathrm{NH}_{4} \mathrm{H}_{2} \mathrm{PO}_{4}$ (pH 4.0) with $1.5 \%$ $(\mathrm{v} / \mathrm{v})$ acetonitrile. Non-methylated $\lambda$-phage (SigmaAldrich) and Escherichia coli DNA were used as the calibration reference and control, respectively. The DNA $\mathrm{G}+\mathrm{C}$ content was determined as $38.5 \mathrm{~mol} \%$.

Both novel strains were tested for the presence of a cytolethal distending toxin $(c d t B)$ encoding gene by using the degenerative primers VAT2, WMI1 and DHF1 as described by Chien et al. (2000). DNA from H. hepaticus LMG $16316^{\mathrm{T}}$ was used as a positive control. For strains $\mathrm{EqF}^{\mathrm{T}}$ and $\mathrm{EqF} 2$, the PCR did not produce the amplicons expected.

The data from the present study indicate that strains $\mathrm{EqF}^{\mathrm{T}}$ and EqF2 represent a single novel taxon within the genus Helicobacter, for which the name Helicobacter equorum sp. nov. is proposed. Analysis of three phylogenetic markers, $16 \mathrm{~S}$ and $23 \mathrm{~S}$ rRNA and $h s p 60$ genes, revealed no specific relationship between this taxon and any of the recognized 
Helicobacter species. Whole-cell protein electrophoresis, a technique known to correlate with whole genome DNADNA hybridization, further demonstrated that there is no specific resemblance between the profiles of these strains and those of established Helicobacter species, indicating that the isolates represent a novel species. Biochemically, this novel species is most similar to $H$. cinaedi with hydrolysis of alkaline phosphatase being the best test to differentiate these species (Table 1). This is the first formal description of a Helicobacter species isolated from horse faeces. Further studies are necessary to define the natural habitat and host range of Helicobacter equorum sp. nov. and to determine its clinical significance and zoonotic potential.

\section{Description of Helicobacter equorum sp. nov.}

Helicobacter equorum (eq.uo' rum. L. gen. pl. n. equorum of horses, from where the type strain was isolated).

Cells are motile, non-spore-forming, curved, Gram-negative rods $(1.5-4 \mu \mathrm{m} \times 0.3 \mu \mathrm{m})$ and carry a single, sheathed monopolar flagellum. Cells do not possess a periplasmic fibril. A thin, transparent spreading film is seen after 3-4 days growth on $10 \%$ horse blood agar. Single colonies are not seen. Coccoid cells predominate in older cultures. Grows microaerobically at $37^{\circ} \mathrm{C}$; no growth is obtained either in aerobic or anaerobic conditions at $37^{\circ} \mathrm{C}$, or at $25^{\circ} \mathrm{C}$ or $42^{\circ} \mathrm{C}$ under microaerobic conditions. Produces oxidase, catalase, alkaline phosphatase, esterase and L-arginine arylamidase. Reduces nitrate. No urease, DNase, $\gamma$-glutamyl transferase, hippuricase, pyrrolidonyl arylamidase or Laspartate arylamidase activity is detected. Indoxyl acetate is not hydrolysed. Triphenyl tetrazolium chloride is not reduced. Neither hydrogen sulphide nor acid are produced from glucose fermentation. No growth is obtained on media containing $1 \%$ glycine, $1 \%$ ox bile, $1.5 \% \mathrm{NaCl}$ or $5 \mu \mathrm{g}$ metronidazole $\mathrm{ml}^{-1}$. Resistant to cephalotin and nalidixic acid. The $\mathrm{G}+\mathrm{C}$ content of the genomic DNA is $38.5 \mathrm{~mol} \%$.

The type strain, $\mathrm{EqF}^{\mathrm{T}}\left(=\mathrm{LMG} 23362^{\mathrm{T}}=\mathrm{CCUG} 52199^{\mathrm{T}}\right)$, was isolated from horse faeces in Merelbeke, Belgium. The clinical significance of $H$. equorum is unknown.

\section{Acknowledgements}

This work was supported by the Research Fund of Ghent University, Belgium, Code GOA 12050602 . This grant is gratefully acknowledged. We want to thank the Department of Internal Medicine and Clinical Biology of Large Animals and the Department of Obstetrics, Reproduction and Herd Health (Faculty of Veterinary Medicine, Ghent University) for their cooperation. We are grateful to Jurgen De Craene and Bart Hoste for their technical assistance.

\section{References}

Baele, M., Baele, P., Vaneechoutte, M., Storms, V., Butaye, P., Devriese, L., Verschraegen, G., Gillis, M. \& Haesebrouck, F. (2000). Application of tRNA intergenic spacer PCR for identification of Enterococcus species. J Clin Microbiol 38, 4201-4207.
Baele, M., Chiers, K., Devriese, L. A., Smith, H. E., Wisselink, H. J., Vaneechoutte, M. \& Haesebrouck, F. (2001). The gram-positive tonsillar and nasal flora of piglets before and after weaning. $J$ Appl Microbiol 91, 997-1003.

Chien, C.-C., Taylor, N. S., Ge, Z., Schauer, D. B., Young, V. B. \& Fox, J. G. (2000). Identification of $c d t B$ homologues and cytolethal distending toxin activity in enterohepatic Helicobacter spp. J Med Microbiol 49, 525-534.

Coenye, T., Falsen, E., Vancanneyt, M., Hoste, B., Govan, J. R. W., Kersters, K. \& Vandamme, P. (1999). Classification of Alcaligenes faecalis-like isolates from the environment and human clinical samples as Ralstonia gilardii sp. nov. Int J Syst Bacteriol 49, 405-413.

Devriese, L. A. \& Oeding, P. (1975). Coagulase and heat-resistant nuclease producing Staphylococcus epidermidis strains from animals. J Appl Bacteriol 39, 197-207.

Dewhirst, F. E., Fox, J. G. \& On, S. L. W. (2000). Recommended minimal standards for describing new species of the genus Helicobacter. Int J Syst Evol Microbiol 50, 2231-2237.

Dewhirst, F. E., Shen, Z., Scimeca, M. S., Stokes, L. N., Boumenna, T., Chen, T., Paster, B. J. \& Fox, J. G. (2005). Discordant $16 S$ and $23 S$ rRNA gene phylogenies for the genus Helicobacter: implications for phylogenetic inference and systematics. J Bacteriol 187, 6106-6118.

Dimola, S. \& Caruso, M. L. (1999). Helicobacter pylori in animals affecting the human habitat through the food chain. Anticancer Res 19, 3889-3894.

Fox, J. G., Chien, C. C., Dewhirst, F. E., Paster, B. J., Shen, Z., Melito, P. L., Woodward, D. L. \& Rodgers, F. G. (2000). Helicobacter canadensis sp. nov. isolated from humans with diarrhea as an example of an emerging pathogen. J Clin Microbiol 38, 2546-2549.

Franklin, C. L., Gorelick, P. L., Riley, L. K., Dewhirst, F. E., Livingston, R. S., Ward, J. M., Beckwith, C. S. \& Fox, J. G. (2001). Helicobacter typhlonius sp. nov., a novel murine urease-negative Helicobacter species. J Clin Microbiol 39, 3920-3926.

Germani, Y., Dauga, C., Duval, P., Huerre, M., Levy, M., Pialoux, G., Sansonetti, P. \& Grimont, P. A. D. (1997). Strategy for the detection of Helicobacter species by amplification of $16 \mathrm{~S}$ rRNA genes and identification of $\mathrm{H}$. felis in a human gastric biopsy. Res Microbiol 148, 315-326.

Houf, K., On, S. L., Coenye, T., Mast, J., Van Hoof, J. \& Vandamme, P. (2005). Arcobacter cibarius sp. nov., isolated from broiler carcasses. Int J Syst Evol Microbiol 55, 713-717.

Jalava, K., Kaartinen, M., Utriainen, M., Happonen, I. \& Hänninen, M.-L. (1997). Helicobacter salomonis sp. nov., a canine gastric Helicobacter sp. related to Helicobacter felis and Helicobacter bizzozeronii. Int J Syst Bacteriol 47, 975-982.

Mast, J., Nanbru, C., van den Berg, T. \& Meulemans, G. (2005). Ultrastructural changes of the tracheal epithelium after vaccination of day-old chickens with the La Sota strain of Newcastle disease virus. Vet Pathol 42, 559-565.

Melito, P. L., Munro, C., Chipman, P. R., Woodward, D. L., Booth, T. F. \& Rodgers, F. G. (2001). Helicobacter winghamensis sp. nov., a novel Helicobacter sp. isolated from patients with gastroenteritis. J Clin Microbiol 39, 2412-2417.

Mesbah, M., Premachandran, U. \& Whitman, W. B. (1989). Precise measurement of the $\mathrm{G}+\mathrm{C}$ content of deoxyribonucleic acid by highperformance liquid chromatography. Int J Syst Bacteriol 39, 159-167.

Mikkonen, T. P., Kärenlampi, R. I. \& Hänninen, M.-L. (2004). Phylogenetic analysis of gastric and enterohepatic Helicobacter species based on partial HSP60 gene sequences. Int $J$ Syst Evol Microbiol 54, 753-758.

Mills, C. K. \& Gherna, R. L. (1987). Hydrolysis of indoxyl acetate by Campylobacter species. J Clin Microbiol 25, 1560-1561. 
Murray, R. G. E., Brenner, D. J., Colwell, R. R., De Vos, P., Goodfellow, M., Grimont, P. A. D., Pfennig, N., Stackebrandt, E. \& Zavarzin, G. A. (1990). Report of the ad hoc committee on approaches to taxonomy within the Proteobacteria. Int J Syst Bacteriol 40, 213-215.

On, S. L. W. \& Holmes, B. (1991). Effect of inoculum size on the phenotypic characterization of Campylobacter species. J Clin Microbiol 29, 923-926.

Patterson, M. M., Schrenzel, M. D., Feng, Y., Xu, S., Dewhirst, F. E., Paster, B. J., Thibodeau, S. A., Versalovic, J. \& Fox, J. G. (2000). Helicobacter aurati sp. nov., a urease-positive Helicobacter species cultured from gastrointestinal tissues of Syrian hamsters. J Clin Microbiol 38, 3722-3728.

Pot, B., Vandamme, P. \& Kersters, K. (1994). Analysis of electrophoretic whole-organism protein fingerprinting. In Modern Microbial Methods: Chemical Methods in Bacterial Systematics, pp. 493-521. Edited by M. Goodfellow \& A. G. O'Donnell. Chichester, UK: Wiley.

Robertson, B. R., O'Rourke, J. L., Vandamme, P., On, S. L. W. \& Lee, A. (2001). Helicobacter ganmani sp. nov., a urease-negative anaerobe isolated from the intestines of laboratory mice. Int J Syst Evol Microbiol 51, 1881-1889.

Simmons, J. H., Riley, L. K., Besch-Williford, C. L. \& Franklin, C. L. (2000). Helicobacter mesocricetorum sp. nov., a novel Helicobacter isolated from the feces of Syrian hamsters. J Clin Microbiol 38, 1811-1817.
Stackebrandt, E. \& Goebel, B. M. (1994). Taxonomic note: a place for DNA-DNA reassociation and 16S rRNA sequence analysis in the present species definition in bacteriology. Int J Syst Bacteriol 44, 846-849.

Steele, T. W. \& McDermott, S. N. (1984). The use of membrane filters applied directly to the surface of agar plates for the isolation of Campylobacter jejuni from feces. Pathology 16, 263-265.

Vandamme, P., Harrington, C. S., Jalava, K. \& On, S. L. W. (2000). Misidentifying helicobacters: the Helicobacter cinaedi example. J Clin Microbiol 38, 2261-2266.

Van den Bulck, K., Baele, M., Hermans, K., Ducatelle, R., Haesebrouck, F. \& Decostere, A. (2005). First report on the occurrence of 'Helicobacter heilmannii' in the stomach of rabbits. Vet Res Commun 29, 271-279.

Van den Bulck, K., Decostere, A., Baele, M., Vandamme, P., Mast, J., Ducatelle, R. \& Haesebrouck, F. (2006). Helicobacter cynogastricus sp. nov., isolated from the canine gastric mucosa. Int J Syst Evol Microbiol 56, 1559-1564.

Whary, M. T. \& Fox, J. G. (2004). Natural and experimental Helicobacter infections. Comp Med 54, 128-158.

Wolf, P. L., Russell, B. \& Shimoda, A. (1975). Bacteriology. Section 13. Reagents and tests used for identification. In Practical Clinical Microbiology and Mycology, Techniques and Interpretations, pp. 254-270. Edited by P. L. Wolf. USA: Wiley. 